\title{
Older residents' experiences of islandness, identity and precarity: Ageing on Waiheke Island
}

\author{
Laura Bates \\ Human Geography Program, University of Alberta, Canada \\ lbates@ualberta.ca
}

Tara Coleman

School of Environment, The University of Auckland, New Zealand

t.coleman@auckland.ac.nz

Janine Wiles

School of Population Health, The University of Auckland, New Zealand

j.wiles@auckland.ac.nz

\section{Robin Kearns}

School of Environment, The University of Auckland, New Zealand

r.kearns@auckland.ac.nz (corresponding author)

\begin{abstract}
Island living can entail many difficult or challenging experiences for individual residents, as well as for island communities at large. We use a multifaceted understanding of precarity and resilience to conceptualise these island challenges, as experienced by older island residents. We focus on Waiheke Island, an offshore island that sits within the greater Auckland area, where experiences of entangled precarities can be observed. Our work explores older renters' experiences on Waiheke Island in order to understand how uncertainties related to ageing, housing and community may influence experiences of islandness, especially as the island's community and environment change in response to recent influxes of tourists and new residents. By reviewing local media reports and conducting two phases of interviews with older renters, we investigate the intersecting precarities of island residence, rental tenure and older age in this rapidly changing island context. Findings illustrate the complexity of home, community and identity-related aspects of island life. Participants' experiences of islandness were influenced by multifaceted precarities in their personal situations and in the broader island community. Despite these challenges, older island renters drew resilience from their enjoyable engagements with places and people, and their emotional attachments to their island home.
\end{abstract}

Keywords: ageing, community, home, housing, islands, precarity, New Zealand, Waiheke Island

https://doi.org/10.24043/isj.92 • Received November 2018, accepted June 2019

(C) 2019-Institute of Island Studies, University of Prince Edward Island, Canada. 


\section{Introduction}

In light of recent interest in the social distinctiveness, community, and identity dynamics of island contexts (e.g. Baldacchino, 2012, 2018; Burholt et al., 2013; Kearns \& Collins, 2016; Róin, 2014), we investigate precariously placed residents' experiences of islandness (Baldacchino, 2004, 2012; Grydehøj, 2017) and the island as 'home'. With this understanding of the particularities of conducting research in an island setting, we ask how experiences of distance and difference can amount to 'precarity' in residents' individual and collective experiences of island life and community. We focus in particular on an example of older renters on Waiheke Island, located 35 minutes by ferry from downtown Auckland, New Zealand, and the most populous of Auckland's offshore islands.

We take the view that islandness is both central to the experience of renting and ageing on Waiheke, as well as to providing the context within which these experiences are placed. In other words, bearing in mind that different kinds of islands have different qualities (Grydehøj, 2019), the material expression of islandness often gives rise to expressions of "boundedness, smallness, isolation and fragmentation" (Baldacchino, 2018, p. xxv). Yet these are necessary but insufficient ingredients for considering contexts of remote or peripheral island life. Rather, subjective experience is central, with islandness adding nuance to the contours of human experience. We therefore consider islandness to be a potential source of challenge, uncertainty and precarity (Waite, 2009) in residents' everyday lives. Waiheke Island is characterised by relatively small neighbourhoods, rural open farmland, wineries and vineyards, and a mixture of rocky and sandy beaches. Its holiday 'feel', tourist appeal and detachment from mainland Auckland's busyness contribute to an idealised island image and identity. The Waiheke Community Board's Essentially Waiheke (2016) report describes the island's "passionate, vocal [...] resourceful" community of people who share a "special sense of belonging [... and are] proud of their status as Waihekeans." Once home to "longer-term alternative life-stylers," Waiheke was historically dubbed a "refuge for the bad, the sad and the mad" and a "hippie hangout" (characteristics that still prevail, albeit to a lesser extent) (Bailey, 2017; Little, 2016). More recently, Waiheke's popularity as a tourism destination has sharply increased over the last 20 years, largely due to enhanced accessibility (faster and more frequent ferries) from mainland Auckland, as well as increased online awareness of Waiheke's scenery, vineyards and art installations, among other features. In 2017, the island was rated by Lonely Planet as the fourth-best island in the world, as well as being Trip Advisor's best island to visit in the South Pacific. Waiheke has been part of Auckland City since 1989, yet residents are generally more focussed on their collective identity than that of the city at large. Hence, in terms of relational islandness, Waiheke is, on balance, "island conscious and mainland unconscious," as Hong (2017, p. 7) observed for Zhuhai in China.

Behind the glossy island-idyll veneer, however, steeply rising property values and rental costs have mirrored mainland Auckland's housing crisis. On the island, the effects of Auckland's 'super-heated' housing market have been amplified by Waiheke's relative isolation, boundedness and desirability for visitors and prospective new residents. Parallel to this concern is the seasonality of the rental market on Waiheke, with reports of renters being tied to short-term tenancy contracts and/or being forced from rental homes prior to the summer tourist season (Auckland DHB, 2016; Gulf News, 2016d). The island's population can swell to $14,000+$ over summer; almost double its permanent population of 8,238 
(Pritchard, 2013). During this peak season, houses may be rented as holiday homes for a nightly rate comparable to (if not exceeding) that ordinarily charged per week to residential tenants (often NZ $\$ 300+$ per night during peak months) (Auckland DHB, 2016).

In this paper we focus on the precarities related to rental tenure and older age, and how these might influence and be influenced by experiences of islandness in this rapidly changing context. We begin by outlining precarity and island studies literature, before considering the specificities of the Waiheke context in more detail. We then describe our methods, before presenting findings from our media review of Waiheke's local newspaper and from two phases of interviews with older renters on the island. Finally, we reflect on these findings in terms of the precarities evident within the island community - both for individual residents, as well as for the collective island identity.

\section{Precarity and island life}

Island contexts have distinctive environmental, accessibility and community characteristics that can influence residents' experiences of ageing and everyday life (Burholt et al., 2013; Coleman \& Kearns, 2015). While many aspects of this 'islandness' are desired and appreciated by residents, the challenges associated with island life, and the insecurities more generally associated with rental tenure, involve multiple overlapping precarities and related expressions of resilience in older age. Waite (2009, p. 426) explains that a precariously placed individual's everyday experiences are "characterized by uncertainty and insecurity." While daily life unavoidably entails some level of risk or uncertainty, a range of intersecting factors can heighten precarity for some places, individuals and communities (Grenier et al., 2015; Nowicki, 2017). Previous research (Groot et al., 2017; Harris \& Nowicki, 2018; Waite, 2009) has highlighted the complexity of precarious experiences, which can encompass the uncertainties and insecurities associated with financial and housing environment situations, personal and health circumstances, and social and community dynamics of everyday life. In this sense, precarity can be a 'backdrop' to a person's daily life, coming to the fore in particularly uncertain situations, or it may take more of a leading role in a person's routines, social activities and sense of place. The combined effects of these different aspects of precarity can have variable implications in people's everyday lives (McKee et al., 2017). We are particularly interested in how such multifaceted precarity is manifested and experienced in place (Waite, 2009), and especially at two levels of place: the localised scale of the dwelling, and the broader scale of the island community.

Interrelated and overlapping dimensions of precarity and resilience are evident in ageing, housing and island experiences. Considering precarity and resilience in tandem can minimise the potential for precariously placed people to be stigmatised or seen as passive victims in the face of uncertainty and insecurity (DeVerteuil \& Golubchikov, 2016; McKee et al., 2017; Pendall et al., 2012; Worth, 2016). Pendall et al. (2012, p. 272) define resilience as "success under stress." Wiles et al. (2012, pp. 416-417) explain this concept in more depth, noting that resilience is "multidimensional and contextualised," entailing "individual and environmental factors" that form the resources a person may draw on in order to "successfully cop[e] with adversity." Beyond the potentially passive notion of "coping', resilience can also involve more active means of overcoming difficulties or changing one's circumstances (DeVerteuil \& Golubchikov, 2016). Understood in this way, resilience refers to adaptability, 
resourcefulness and agency; the human reactiveness and responsiveness that may be observed in the activities and routines of people who are precariously placed. Such resilience may be related to personal considerations (e.g., individual preferences, health or financial circumstances), environmental factors (e.g., housing, neighbourhood), and social support and connections (e.g., friends, family, community services) (Wiles et al., 2012).

Islands can be precarious places where residents may encounter financial, housing, social and health-related challenges. The cost of living can be driven up on islands by tourism popularity and freight costs related to distance from a major city or mainland, meaning residents may face financial challenges, especially regarding affordability of everyday needs, such as food and housing (Brown \& Cave, 2010; Green, 2005; Pritchard, 2013). These heightened costs can be particularly problematic for residents with insecure or low income, including retirees. Relatedly, distance from mainland healthcare facilities can be problematic for some islanders, especially older residents or others who may experience heightened need for these services (Róin, 2014). Moreover, Botterill (2016) noted that older British migrants' experience of widely romanticised island retirement aspirations in Thailand could be undermined by precarious and insecure housing tenure, even if the house itself was physically 'luxurious' and satisfied their needs. In this sense, tenure security, housing quality and retirement plans can be seen as intersecting in older people's variable experience of precarity.

The bounded and distanced nature of an island can also have complex and variable implications for residents' social lives. Islandness can exacerbate the shrinking of an older person's support network, given that moving off-island, or having friends/family move offisland, can place distance, time and financial barriers between the older person and their friends and family (Coleman, 2012; Róin, 2015). Alternatively, older people may also be supported and enabled by a cohesive community, as can commonly (although not always) be found within island settings (Hay, 2006). Place attachment and enjoyment of the island landscape can also bolster older islanders' resilience and wellbeing (Coleman \& Kearns, 2015; Róin 2015). Such enjoyment of islandness can again be precarious, however, in light of island gentrification and arrival of new residents and visitors who might be perceived to alter the collective identity and community character (Baldacchino, 2012).

Thus, an island context can contribute to older residents' precarity and their resilience, with variable implications that are largely contingent on personal circumstance (Bates et al., 2019; Burholt et al., 2013; Coleman \& Kearns, 2015). Islands are places where experience(s) of precarity can be both expected, and adapted to, by island residents (Brown, 2017; Burholt et al., 2013). In this paper, we apply this conceptualisation of precarity and resilience as intertwined and multifaceted, in order to understand how islandness is experienced by precariously placed older renters. In considering potential precarities of renting in older age, we view Waiheke's island context as an intensifier of both the housing context and of experiences of place attachment, collective identity and community change.

\section{Ambiguous island experiences}

The social and aesthetic appeal of islands to visitors and new residents can give rise to changes, tensions and challenges within an island community. Tourism can be beneficial to island economies, but may also contribute to a sense of lost community and identity, especially when residents feel outnumbered, if not displaced, by visitors who are felt to be changing or 
contradicting the island's character (Baldacchino, 2012; Burholt et al., 2013; Hay, 2006). Tourism can bring the introduction (or imposition) of tourist-specific facilities, and social and environmental problems related to increased visitor numbers (Brown \& Cave, 2010; Green, 2005). In these ways, tourism can be seen to amplify precarity for island places, residents, communities and identities. It can result in 'bridging' (literally or figuratively) between the island and the mainland, with enhanced accessibility decreasing an island's insularity and isolation, thereby altering aspects of its community character and landscape (Baldacchino, 2012; Hay, 2006). Increased accessibility between an island and its mainland can result in changes to the island population and popularity, as has been observed for Waiheke. As Leung et al. (2017) discussed with respect to Hong Kong, these changes can have implications not only for residents' sense of community, distance and difference from the mainland, but also lead to changing environmental and economic effects as new developments and infrastructure are introduced.

Older residents often enjoy island life for the same reasons these places have tourist appeal. While many older residents are 'long-term islanders', who have formed strong place attachments over many years (Coleman, 2012; Róin, 2014, 2015), for some an island can be seen as a desirable retirement destination despite having little or no previous connections to the island (Bell, 2017). The motivations and interests for tourists and older 'retirement migration' residents overlap, especially in terms of their enjoyment of scenic landscapes and a general sense of wellbeing experienced in/through island places (Burholt et al., 2013; Coleman \& Kearns, 2015; Hay, 2006). Such benefits to wellbeing and enjoyment of islandness can contribute to older people's resilience in island settings.

Islands can also have 'darker' connotations behind their idealised "imag(in)ery" (Burholt et al., 2013; see also Baldacchino, 2012; Bell, 2017; Hay, 2006). Previous work has considered detention centres (Mountz, 2011), tourism-driven community displacement (Green, 2005) and population decline (Royle \& Scott, 1996) on islands. Moreover, despite being favoured retirement destinations, islands are typically distanced from a range of key ageing-related facilities and services. Such challenges can amount to an on-island amplification of the precarities associated with ageing and rental tenure elsewhere, with older island residents often encountering rising living costs, limited healthcare facilities and isolation from family and friends residing off-island (Bates et al., 2019; Botterill, 2016; Coleman et al., 2016; Gould \& Moon, 2000; Hay, 2006). Yet Coleman and Kearns (2015) explain that island 'bluespaces' can also contribute to older islanders' life enjoyment, sense of place and personal identity, and ultimately their wellbeing. We contend that such positive island experiences can contribute to older islanders' resilience in the face of 'darker' aspects of island life, including community, housing and ageing-related precarities.

\section{Context}

As of 2013 Waiheke had 8,238 permanent residents, 34.1\% of whom were over 55 years of age (considerably higher than the Auckland regional and national New Zealand proportions: 21.9\% and 25.9\% respectively). Located within the Greater Auckland region (see Figure 1), Waiheke has been part of Auckland City since 1989. Ongoing resistance to ties to the mainland prevails, with continued efforts by some community groups to re-establish independent governance on the island (Gulf News, 2016d). 


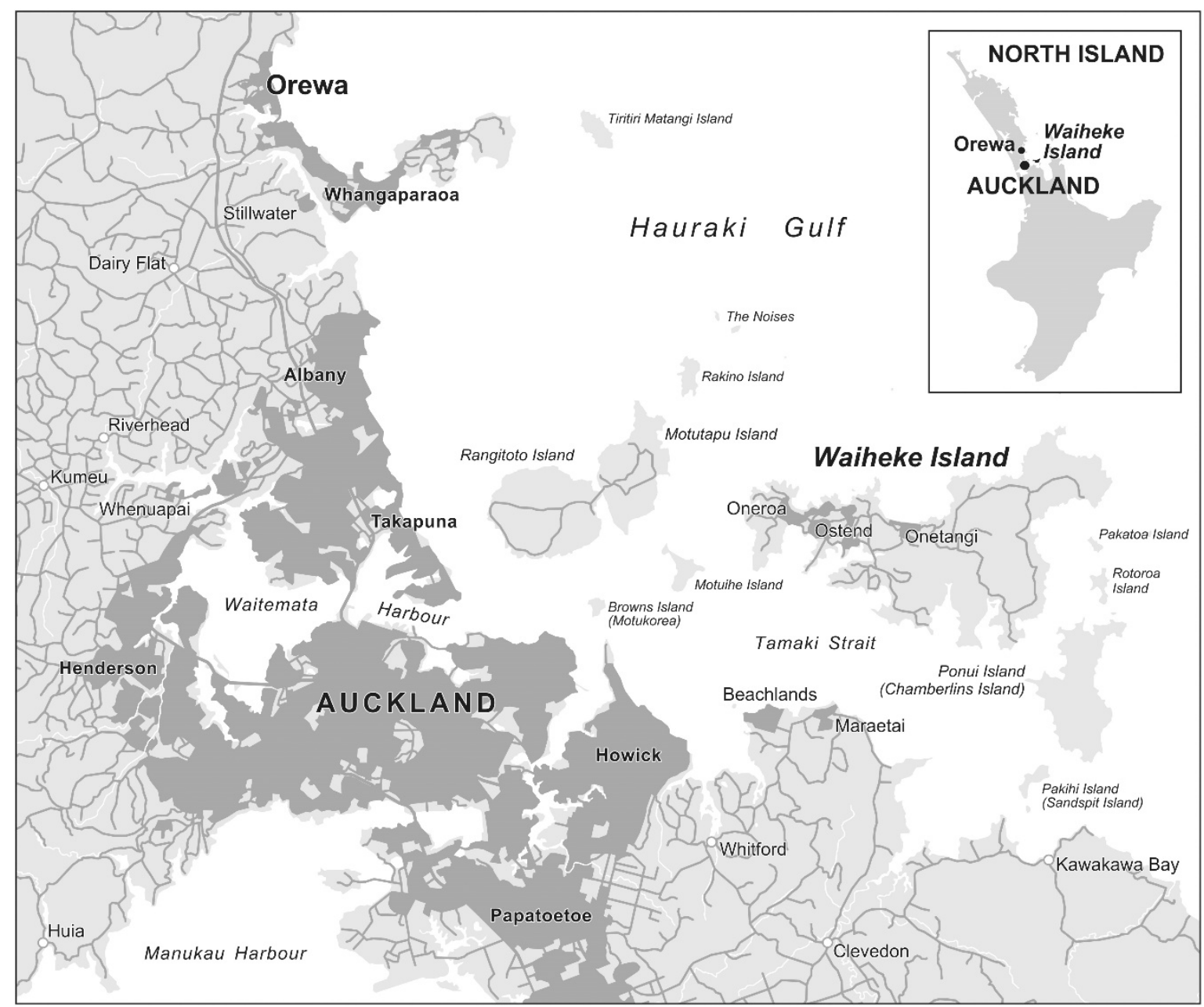

Figure 1: Map showing Waiheke and greater Auckland region. Source: School of Environment, University of Auckland.

With a recent surge in tourism popularity, Waiheke is rapidly changing to accommodate influxes of visitors and (typically much wealthier) new residents. The acceptance or even promotion of "economic diversity" (Waiheke Community Board, 2016) has been unsettling and displacing for some 'old Waihekean' residents (Little, 2016). Although the island retains its distinctive identity and reputation as a retreat, changes are highly visible in places-particularly in the contrast between older or 'traditional' Waiheke baches (holiday cottages) and newer, typically larger and more luxurious, residences. Waiheke has become an intensified outpost of Auckland, with its housing unaffordability often mirroring, if not amplifying, many of the issues being experienced on the urban mainland.

Waiheke's prevailing reputation, tourism promotion and collective community identity paint a picture of social harmony, creativity and environmental beauty that amounts to an island idyll. The island's inequalities tend to be unseen, or at least under-recognised. As the Auckland District Health Board's Waiheke Island Service Review (2016) notes, many of Waiheke's houses are converted holiday dwellings, never intended for year-round residence. These houses are frequently un(der)insulated, and/or may have long-standing maintenance problems. In addition to such housing quality concerns, Waiheke's ageing population, combined with an under-supply of some health and ageing services, and distance to mainland facilities, can make it a particularly challenging place for older islanders. For those who are 
renters, these difficulties may be compounded by insecure or short-term tenancies and higher rental costs than are typically charged in less tourism-oriented places. Given Waiheke's bounded community context and high-pressure housing market, our concern is to explore the potential precarities and inequalities within the island community, lying behind its otherwise idealised image and identity.

\section{Methods}

To explore issues of renting and ageing within this complicated island context, we employed qualitative research methods (interviews and narrative analysis) to ask: How is islandness experienced by precariously placed older residents? We were specifically interested in the intersecting precarities faced by those who are ageing in rented housing within the island context. We defined 'older people' as aged 55+, recognising that ageing is an ongoing process that can affect people's decisions and activities before formally retiring from employment (Costa-Font et al., 2009; Craciun \& Flick, 2014).

\section{Data collection}

To provide a sense of Waiheke's unique context, we began by reviewing media reports published in the island's newspaper, the Gulf News (2016-17), concerning social and community issues and local housing concerns. Following the approach used by Lawrence et al. (2008), we initially identified keywords of particular relevance, including 'housing', 'renting', 'ageing' and 'community'. Analysis of the 32 articles identified in our searches entailed close reading and comparison of the media reports, with particular attention paid to themes of island identity and characteristics, housing, and social and community support. Contemporaneous with this media survey, we made initial visits to key social and health services on the island. These enabled us to further understand the current ageing and renting context, and also distribute informational flyers to older renters. These potential participants could then contact the researchers for more information or to arrange an interview time (an indirect recruitment method approved by the institutional ethical committee).

In order to understand more closely the experiences of older renters within the Waiheke context, we conducted two phases of interviews: the first involving thirteen older renters, and the second involving five of these participants in follow-up interviews. Phase 1 interviews were approximately 1.5 hours in duration, with two interviewers present to facilitate a comfortable and conversational 'flow'. Interview questions explored issues of tenure security, residential mobility, dwelling quality, community involvement, health and ageing and experiences of island life. Information was also collected regarding socio-demographic details, specific housing characteristics and access to or use of community amenities.

While undertaking the initial interviews with older renters, the first and second authors took extensive handwritten notes, rather than audio-recording. This decision was made on account of the sensitive and confidential nature of the topics discussed. The presence of two interviewers enabled thorough handwritten notes to be recorded and later discussed and corroborated, thus ensuring interview details were recorded accurately and in-depth. As also noted in other research contexts (e.g., Garg, 2006; Stake, 1995), our thorough handwritten notes enabled accurate documentation of the ideas expressed during the interview conversation, as well as a number of direct quotations. Non-recording of interviews was 
intended to encourage and put at ease participants who might otherwise be tentative to discuss potentially emotionally fraught topics in a more formal setting. Putting participants at ease in this way was particularly important in this fieldwork given the highly sensitive and emotional nature of some of the matters discussed (including ambiguous experiences of home, financial or housing insecurity, and health and family circumstances) (Clarke, 2006; Liamputtong, 2007; McGarrol, 2017). Moreover, non-recording of these initial interviews enabled the greatest protection of participants' identity given the unique challenge of conducting interviews in a small island community, where anonymity could be easily compromised because most participants were familiar with each other. These interviews generated rich personal narratives, with transcripts for each Phase 1 interview being 20-30 handwritten pages in length.

In Phase 2, semi-structured interviews explored the issues raised in Phase 1 in more depth, with conversations lasting 1-2 hours. Follow-up participants were selected based on the diversity of their housing quality and residential mobility experiences, as well as their willingness to be re-interviewed and their eligibility (continued residence on the island). Questions were open-ended and conversational, enabling participants to share their stories in their own way (Liamputtong, 2007). Having established a sense of trust and rapport during the initial phase of data collection, follow-up participants felt comfortable providing written consent for audio-recording of Phase 2 interviews. These recordings were subsequently transcribed in full by the interviewer, as soon as possible after the interview, resulting in 1014 typed pages of narrative data for each follow-up interview.

\section{Narrative data analysis}

We analysed our qualitative data through undertaking a close reading of individual participants' accounts, as well as drawing out common themes across different participants' experiences (see Maxwell \& Chmiel, 2014). This approach meant that we could preserve congruence within individual stories, while also establishing similarities and comparisons across participants' accounts within the data set. Narratives from both interview phases were grouped by prevailing themes that we identified in our interviews, as well as those identified in the media review and in relevant academic literature. We have selected illustrative quotations, presented below, to provide insights into participants' experiences. Observational notes, made as soon as possible after each interview, were also utilised during analysis to facilitate a deep and holistic understanding of each participant's personal context (Kearns, 2016; Merriam \& Tisdell, 2016). Examples of supplementary information that was drawn from post-interview notes included the tone and pace of the interview, physical housing characteristics and the details of particularly emotional conversations.

\section{Results: a media review}

The Gulf News, Waiheke's local newspaper, plays an important role in circulating information about current affairs and events on the island and provides a useful insight into Waiheke's context and community. It contributes to (re)production of the island identity, and is regarded fondly by many island residents. Our search of the Gulf News online database identified 32 relevant media reports (2016-17) that discussed issues associated with housing, renting, ageing 
and community. We have grouped the media reporting relevant to our investigation of island precarity and resilience around three themes: island identity and changing characteristics; housing availability and affordability; and community support. We explore each of these themes in this section, before presenting and discussing our older renters' experiences of Waiheke Island.

\section{Island identity and characteristics}

Owing, perhaps, to a strongly defined collective identity on the island, a striking majority of local media reports and opinion pieces made some reference to Waiheke's community characteristics and distinctiveness. Some commented on its scenic and environmental qualities (e.g., Gulf News, 2017e, 2017i), while others observed the community's strong artistic interests (e.g., Gulf News, 2017f) and political engagement (e.g., Gulf News, 2017g, 2017l). In most cases these aspects of island life and identity were perceived to be threatened. Many local residents, activists and reporters felt that the nature of the island was changing, or even "disappearing" with the increased numbers of tourists, new residents, more frequent ferry sailings, private helipads and diminished community spirit (Gulf News, 2017a, 2017j, 2017k, 2017m).

Further, tensions between the values and lifestyles of tourist visitors and those of many island residents were frequently highlighted. As one Gulf News commentator explained: "Few of us here want to be judged on the tribal behaviour of some of our summer visitors. Selfies with chardonnay and the helicopter are not our resting state" (Gulf News, 2017b). Such usand-them distinctions were used in local media descriptions with respect to the 'tourists' and 'residents' binary, as well as between "old" and "new" Waihekeans, and also between permanent island residents and second-home owners residing primarily off-island (Gulf News, 2016b, 2017b, 2017j, 2017f). Thus, what is often portrayed and imagined as a harmonious and supportive small-island community can be fragmented, strained and made precarious by tensions between different groups of residents and visitors.

\section{Housing on Waiheke}

Local media also paid considerable attention to issues of housing availability, affordability and quality; all pertinent concerns in the Waiheke context given that many of the island's dwellings are converted holiday dwellings never intended for year-round residence. In addition to the contrast between 'up-market' mansions and lower-quality housing, there were reports of some island residents being literally homeless or living in emergency accommodation, or informal dwellings including non-self-contained cabins, tents, cars and houseboats (e.g., Gulf News, 2016a, 2016b, 2016c).

One commentary explained how housing pressures were slowly changing the community from "complete" to "elite," with implications for people's ability to live and work on the island (Gulf News, 2016a). The writer mentioned that such challenges could be exacerbated by high vacancy rates during the off-peak season, with elite holiday houses being "hollow [...] ghost homes" for large portions of the year, while less-wealthy residents struggled to afford rent increases or were 'forced' to move off-island in pursuit of available and affordable housing (Gulf News, 2016a, 2016b, 2017c). Local reports indicated that these housing precarities were especially prevalent among young families, single parents and older people (Gulf News, 2016a, 2016b, 2017d). A mismatch was also observed between the types of housing available on the island, and the types of people seeking accommodation. In 
particular, the paper reported that Waiheke's higher-than-average proportion of single people living alone commonly struggled to find, afford and remain living in suitable accommodation, largely due to financial pressures (Gulf News, 2016a, 2016b).

\section{Social and community support}

In response to these housing and affordability stresses, the community has rallied to support fellow residents. This outpouring of support reflects what has been described in general reporting of island events and social issues as Waiheke's "far from perfect, but [...] strong and caring community" (Gulf News, 2017g). This caring community has been manifested in a range of non-governmental services and community organisations. The Gulf News has often promoted and advocated for these groups, especially during fundraising events or times of heightened challenges within the community. One initiative highlighted is "The Doctor's Wallet": a ferry ticket and NZ $\$ 10$ cash package distributed by general practitioners to help with travel and sustenance expenses for patients requiring hospital treatment in Auckland (Gulf News, 2017h). The same article also described how the Waiheke Red Cross coordinates the island-wide delivery of Meals on Wheels to elderly and disabled residents, and financial or practical assistance to households struggling with housing costs (Gulf News, 2017h). These initiatives rely on donations and volunteer labour from the local community. Despite often observing the challenges and tensions within Waiheke's population, the Gulf News also frequently highlighted how supportive values remain visible and important to collective identity and community life, thus upholding the resilience of the island's residents and community.

\section{Results: older renters' narratives}

Interviews with older renters on Waiheke provided an in-depth experiential understanding of island life and the changing community. Participants ranged from 56 to 73 years of age (mean 65.7 years), including ten women and three men (all referred to using pseudonyms, assigned randomly upon completion of data collection). Weekly rent payments ranged from $N Z \$ 50$ to $N Z \$ 400$ (mean NZ\$262), with five paying more than $N Z \$ 350$. Eight resided in stand-alone houses at the time of our interviews, while three lived in semi-detached units and two were in informal shelters. Participants' lengths-of-residence on the island ranged from 1 to 40 years (mean 17.7 years), with most (7/13) having lived there for more than 15 years. The following sections explore their experiences of life on Waiheke Island.

\section{Enjoyment of island life}

Consistent with many of the ideas highlighted in local media reports, participants described their enjoyment of a range of island experiences. These included Waiheke's small neighbourhoods, ocean views, proximity to multiple beaches and a strong sense of community. Some of these island and community aspects were said to be unique to Waiheke; as Caroline noted, "the island just has something special about it." Others articulated this 'specialness' more specifically:

I like the sea views, I can walk to the beach. It's an excellent community, it has the spirit of $[. .$.$] donating things, everybody gets together, we are united. (Eliza)$ 
I've been coming here from a young age, we had brilliant holidays here. Waiheke is like home. [...] I'm not a city person, I like looking at the trees, birds, dogs. I love Waiheke. (Rose)

[I like] everything about it; it's home. [...] If someone you know needs something, you help - it's just the old Waiheke community way. (Aroha)

These expressions of Waiheke's 'special' qualities clearly, if indirectly, invoke its islandness, extending beyond its material scenery and landscape to include valued aspects of social cohesion and community. For some, the island's beaches were felt to be special as sites that are unique to the island, and seen to reflect Waiheke's community identity and reputation. Beaches also facilitated social interactions, thereby contributing to participants' enjoyment of island life. As Belle explained:

People are friendly, you can chat with strangers at [the beach]. We have wonderful conversations, especially if you're [going for a walk] on your own. My husband has "beach friends" who he sees when he's walking the dog. (Belle)

In addition to Waiheke's beaches, older island residents identified other special places that contributed to their enjoyment of the islandness of their home and community. Three participants made specific mention of the island cinema (filled with donated furniture) as a community place that facilitates social opportunities. It was identified as a meeting place that encapsulates the island's character:

The cinema is a community asset. It's an intimate space, I love the theatre, it promotes social activity and community. (Georgina)

A friend and I go to the movies together [...] [she] has health problems [...] [and] I can't really afford to participate and go places, but I go without meals to be able to pay for the movies. (Eliza)

Despite affordability and living cost challenges, the beaches, cinema and other 'special' community spaces provide opportunities for socialising, and can play a key role in older people's enjoyment of life on Waiheke. Moreover, it seems that Waiheke's distinctive collective identity is related to its distance from the mainland, and this separation was experienced positively by older residents, as Donna explained:

Waiheke is like a different world. [...] When I was commuting, you could get on the ferry and slip the rope, leave the hustle and bustle. It's a friendly and supportive place, a close-knit community. [...] [I like] the ambience, the birdlife, peace and quiet. (Donna)

Waiheke's distinctiveness compared to mainland Auckland fuelled many residents' emotional attachment to the island as 'home' and as a place where they would like to age. However, while such place attachment and familiarity with the island community are 
resources older people may draw resilience from (Wiles et al., 2012, 2017), being at home on the island was also inherently precarious. Participants explained challenges associated with Waiheke's distance from hospitals and other healthcare and ageing services.

In-home support systems are available on-island, but more specialised healthcare facilities and medical appointments typically involve a ferry trip to Auckland. As Wallis remarked, he "only go[es] into town for the hospital." Others also commented on the challenges and uncertainties posed by their reliance on mainland Auckland's medical facilities, especially in older age, despite their enjoyment of island life:

The island is ideal for ageing [...] [unless] you've got major health concerns, [then] you end up [in Auckland]. But if it's just old age [...] it's the best place in the world! [...] You don't need a vehicle, [...] we're surrounded by the ocean, not much pollution. [...] I don't think town is a healthy place for anybody. (Rose)

Access to health services is important [for older people]. There's [few] [...] doctors or physio[therapist]s on Waiheke. This is especially a problem as it's expensive to travel to Auckland, and hard to schedule different appointments on the same day so you can take time off work. [...] Ferry costs are unfriendly to people who are unwell. (Felicite)

In addition to time- and cost-related challenges, city-bound medical trips can be stressful, especially for those who do not often visit the mainland. Although participants spoke mostly about short-term trips to the city for appointments or hospital stays, some older residents are forced to move off-island to receive longer-term or residential care. As Rose mentioned, this places barriers between friends and changes older people's support networks:

There are too many people being shipped off the island [to receive care]. [...] I like to visit [my friend] in hospital in Auckland, but it's so expensive on the ferry and the bus. [...] She's screaming to get back, she misses her quilting group, her embroidery group, everything about home.

For Rose and her friend, the distance between the island and the hospital placed distance in their friendship. Moving out of a familiar community disrupted the mutual support arrangements Rose's friend had established, and reduced their previously regular contact. Hence, while social connections within a supportive island community can enhance interviewees' experience of ageing in place, Waiheke's distance from mainland facilities can add to the precarities associated with older age.

\section{Island community change}

Parallel to these island challenges, participants particularly disliked changes to the island lifestyle and community. One of the most commonly cited disadvantages of living and ageing on Waiheke was the influx of tourists and 'new money'. Some attributed the 'problem' of Waiheke's changing character to tangible, material changes observed on the island: 
I don't like $[\ldots]$ that it's becoming very elitist here. [...] It's almost as busy in winter as in summer now. [...] [It's] overwhelming. (Georgina)

A lot of elderly people miss out on having a cup of tea or coffee at the local [café]. [...] Years ago, we could travel from here to [local café] [...] and [lunch] didn't break the bank. But then [...] [one day] it [cost] almost the power bill. We never did it again. (Rose)

Waiheke is so changed since I first came here [...] it's just not the Waiheke I knew [anymore]. It's a shame. (Avery)

These changes were perceived to be detrimental to the island's landscape and community, with implications for residents' everyday activities and life enjoyment. In addition to these issues, others described changes to the island community and identity in terms of the new residents and the competing ideas and values they were perceived to bring to Waiheke:

It's not as good as it used to be. [...] The new Waiheke people [...] have a different mindset, they bring city places and ideas into the island and chop down trees. [...] They're seeking status; they aren't community-minded. (Caroline)

I like the island's atmosphere, ambience. It used to be nicer. The people responsible for gentrification are heartless people; they come to show off their wealth and they need the poor here to do that. (Stewart)

There are lots of rich people moving in, with not the same values as old locals. There's a 'them' and 'us'. They are trying to turn the island into what they're used to. It's not fair. I don't like the empty houses when people need somewhere to live and have to move off the island. (Aroha)

In response to these undesired changes on Waiheke, participants had developed coping strategies and resilience mechanisms to maintain their enjoyment of the island. For some, these strategies involved drawing on local knowledge they had accrued through long-term island residence:

We [Waihekeans], have a whole winter and we can go to the beach, swim and play, take our animals, and there's a freedom that you can't have [in summer]. [...] [But] if you live on the island, you know [...] different places where there's no-one. [...] They might be difficult to get to, [but] there's a freedom in that. You can't do that in the city. (Rose)

I've been on the island a long time, so I know where to go. [...] If it's a lovely day and I'm sitting here in the shadow and the gloom, I take myself off to [the beach]. [...] I know a lot of people [...] I'll go somewhere and invariably run into somebody 
I know. [...] All my friends are here, [...] I feel really comfortable [on Waiheke]. (Donna)

These participants' use of (or retreat to) these "out of the way little places" (Rose) reflects their adaptability in the face of changes and challenges: they adjusted their activities and consumption of island places to minimise the impacts of Waiheke-wide changes in their personal lives. The knowledge these participants had accrued through long-term island residence enabled them to adapt to many changes on Waiheke, allowing them to continue to experience the aspects of island life that might otherwise be 'lost' or less accessible with increasing tourism and new (typically wealthier) residents. In this sense, participants were (re)producing island experiences and identities, drawing strength and resilience from aspects of islandness despite the variable changes, challenges and precarities they experienced.

\section{Discussion}

It is clear that there are precarities inherently associated with life on Waiheke. For older renters, challenges and uncertainties were posed by aspects of Waiheke's islandness, particularly its distance from some mainland facilities, especially healthcare services. Additionally, some participants were isolated from family and friends in Auckland, especially given the distance between the city and the island, as well as the time and costs associated with ferry trips. Participants also commented on the cost of living on the island, not only in terms of their housing, but also in terms of supermarket pricing, café meals and other activities. These costs were said to have increased in recent times due to an influx of wealthier new residents and tourists - a sentiment also echoed by local media reports. In this sense, the island context intensified the experience of life on Waiheke by heightening some of the precarities associated with ageing and renting in the island context. As the following sections show, uncertainty and change in community and identity dynamics, as well as in personal island residence circumstances, can intersect and combine to produce precarity in the manifestation of islandness and in older island residents' experiences.

\section{Precarious community and identity}

Waiheke's community identity is precarious in that recent tourism growth and an influx of newer, more affluent residents have contributed to perceived shifts in the island's character, lifestyle and community dynamics. Such changes have implications not only for the island identity and form of the community, but also for individual residents' experiences of a wide range of desired aspects of islandness identified by previous island studies research, including senses of belonging, place attachment and life enjoyment (Baldacchino, 2012; Burholt et al., 2013). Several participants became tearful while reflecting on how Waiheke had changed since they had first moved to the island. However, for many participants, a strong sense of home and attachment to the island endured despite these changes. They often attributed this to the same long-standing emotional and/or nostalgic connections to island places and people that made them upset to observe changes in their community. All but one expressed a desire to remain on the island "no matter what," and the two participants who moved off-island during our research period explained that they would have preferred to stay. As Wiles et al. (2017) also note in their work with older people in a mainland context, well-established social 
networks, place familiarity, local knowledge and a strong sense of home were resources through which older renters could develop independence and resilience in the face of interrelated precarities. In the Waiheke context, such precarities appear amplified and include those associated with material dimensions of islandness (i.e., boundedness, smallness and relative isolation) as well as the sense of collective disruption and the changing community character as visitor numbers increase and housing unaffordability worsens.

Participants disliked most changes they had observed, and felt acutely the loss of some island places or activities that were no longer accessible or enjoyable to them. In response to these changes, participants described strategies developed to live with or around new residents and visitors. Several noted that, as long-term "old Waihekeans," they could draw on their local knowledge to ensure their continued enjoyment of the island by visiting favourite places, "secret spots" and isolated beaches away from popular tourist sites. Some participants also explained how their involvement in community mechanisms (e.g., local volunteer work, or offering neighbourly help, support and transport) enabled them to uphold the "old Waihekean way" and maintain their experience of the island community and identity, as also observed by Burholt et al. (2013) in their work with older residents on small Irish islands. Moreover, maintaining community experiences can be seen as a way of preserving a sense of 'home' and belonging on the island in the face of personal and island-wide change (Róin, 2015). Relatedly, constructing 'them' and 'us' distinctions between "old" and "new" Waihekeans or between "locals" and "tourists," as also evident in media reports and editorials, was a protective resilience strategy expressed by many participants. Through observing and discussing such distinctions, participants could distance themselves from disliked changes on the island, and experience a sense of solidarity with other longer-term Waiheke residents despite influxes of new residents and visitors who were felt to disrupt community values and identity. As Burholt et al. (2013) also observed, in this way resilience to challenges and hardships associated with islandness can be seen as a shared experience, and a key part of island residents' and communities' identity. Our conceptualisation of multifaceted and interacting precarity and resilience illuminates the intricacies of older renters' experiences and responses to the precarious island identity and community. Participants demonstrated their agency and adaptability in the face of complex changes and challenges at the island community scale, as well as at a more individual level.

\section{Precarious islanders}

Participants encountered a range of more personalised precarities alongside those observed in the Waiheke community at large. Many of these were related to the distinct and combined uncertainties of older age and insecure rental tenure. As McKee et al. (2017) and Nowicki (2017) note, precarious experiences are diverse and personalised, and it is clear in participants' stories that the multifaceted (potential) challenges and uncertainties encountered while renting and ageing on Waiheke had variable implications depending on their personal circumstances (see also Grenier et al., 2017).

All 13 participants had experienced some housing challenges or uncertainties, often related specifically to characteristics of Waiheke's housing stock and market. Housing-related precarities included: low-quality or informal dwellings; dangerous, cold, damp houses or under-converted baches (holiday cottages); insecure, short-term or seasonal tenure; vulnerability to sudden eviction and frequent residential mobility; and struggles finding 
alternative accommodation within the high-pressure island housing market. Such diverse island-housing precarities had implications for participants' sense of security, physical safety, wellbeing, social interactions and general life quality-outcomes of precarious housing also noted in Colic-Peisker et al.'s (2015) Australian study. Compounding these housing precarities, all but one participant mentioned pre-existing, chronic or acute health conditions that, as Clarke \& Bennett (2013) also observed, created challenges or uncertainty in daily life in older age. These conditions could be made even more difficult by aspects of the island context, especially distance from mainland hospitals and services or off-island family and friends (Bates et al., 2019; Burholt et al., 2013; Coleman, 2012; Gould \& Moon, 2000; Róin, 2014), as well as the emotional stress experienced through housing precarities. Both local media reports and participant accounts indicated that many of these challenges were upheld or exacerbated by the limited and expensive housing options available on Waiheke-issues that stem from its relative accessibility from mainland Auckland and popularity with visitors and new residents.

Older renters explained varied strategies that enabled them to adapt and cope with personal and island-wide housing stresses, 'making the most of things' even if not improving their living arrangements. As Hillcoat-Nalletamby and Ogg (2014) and Colic-Peisker et al. (2015) also documented, some sought resilience through moving to alternative accommodation in pursuit of secure, better-quality or more affordable housing. Others felt 'trapped' on the island or in low-quality housing, and instead expressed resilience by altering their daily activities and/or some physical attributes of the dwelling (Golant, 2015). While older renters' experiences of housing precarities were clearly diverse, they were nonetheless underpinned by shared uncertainties that could be managed or adapted to through varied resilience strategies.

Participants explained a range of different strategies that enabled them to 'get on with things' in the face of health and ageing uncertainties. When possible, and subject to landlord approval, modifying the dwelling was one resilience tactic that older renters could use to manage their health-meets-housing situation. However, in many cases this was not possible, leading Franklin, Rose and others to seek alternative means of coping with precarity, especially through "accommodative" or "mind" strategies (Golant, 2015) such as maintaining a positive outlook (Wiles et al., 2012). They emphasised that they felt grateful to live on the island, and drew strength and optimism from their enjoyment of the island community and environment, in a similar way to how older homeowners in Coleman and Kearns' (2015) study coped with ageing-related challenges by enjoying island views and bluespaces. Participants also described community support systems (both formalised and informal) that enabled them to be as happy and independent as they could be during times of ill-health, grief, emotional "breakdowns," financial strife or when moving house.

Many felt that this support was related to the closeness of the island community and would not be possible in other (especially non-island) places. This view was similarly observed in Róin's (2015) comparison of older people's experiences of community support in a city and island context (see also Burholt et al., 2013). Such social support mechanisms are wellrecognised resources for resilience, and enabled both (relatively passive) coping with difficult circumstances and (more active) efforts to change one's situation (Golant, 2015; Worth, 2016). As such, the inherently personal and diverse health and ageing precarities faced by participants 
were influenced by Waiheke's islandness, and experienced and managed differently depending on older renters' individual circumstances.

\section{Conclusion}

Our findings have illustrated the combination of uncertainties encountered by older Waiheke renters related to housing, health, ageing, social and community aspects of daily life. We have also observed the intensifying effect of the island context on these multifaceted precarities as they were experienced and responded to by participants. Aspects of Waiheke's 'islandness' had variable implications for older residents' experiences of ageing depending on their personal, social and health circumstances. For most participants, island challenges did not undermine their sense of home on the island, nor their attachment to the Waiheke community. Older island renters are clearly precariously placed, but participants' expressions of resilience were evident in their expressions of agency and adaptability in living with or around personal challenges and undesired changes in the island community and landscape (see also Bates et al., 2019).

We have focussed on one island setting characterised by hybrid urban/rural characteristics. However, our attention to precarity has 'spoken' to broader processes doubtlessly also at play in other island settings affected by escalating housing costs, tourism pressures and metropolitan influence. Despite noting that the island community and identity "used to be nicer," precariously placed Waiheke residents in our study remained loyal to their island home and were determined not to leave the place that provided them with a sense of belonging and life enjoyment. This emotional attachment to the island was so strong that it contributed to older renters' resilience in the face of housing and ageing related precarities. A sense of home on the island could, in some cases, overshadow deeply dissatisfying experiences of place at the more intimate scale of the dwelling as well as disliked changes at the broader scale of the community and identity. We therefore conclude that islands are both precarious and resilient places, where residents and communities may experience multiple overlapping and interacting challenges and opportunities. These precarities, and island residents' associated assertions of resilience, highlight the complex and variable nature of island life beyond and behind the romanticised island idyll.

\section{Acknowledgements}

This project was supported by the Life When Renting Programme led by the Centre for Research, Evaluation and Social Assessment, funded through the New Zealand National Science Challenge 'Ageing Well'.

\section{References}

Auckland District Health Board (DHB) (2016). Waiheke Island service review: A community perspective. Unpublished report. Retrieved from https://www.adhb.health.nz/assets/Documents/Consultations/Waiheke-IslandHealth-Services-Report-2016.pdf 
Bailey, L. (2017, November 5). A guide to Waiheke Island, the Hamptons of New Zealand. Vogue. Retrieved from https://www.vogue.com

Baldacchino, G. (Ed.) (2018). The Routledge international handbook of island studies: A world of islands. London \& New York: Routledge.

Baldacchino, G. (2012). Come visit, but don't overstay: Critiquing a welcoming society. International Journal of Culture, Tourism and Hospitality Research, 6(2), 145-153. https://doi.org/10.1108/17506181211233072

Baldacchino, G. (2004). The coming of age of island studies. Tijdschrift voor Economische en Sociale Geografie, 95(3), 272-283. https://doi.org/10.1111/j.1467-9663.2004.00307.x

Bates, L., Wiles, J., Kearns, R., \& Coleman, T. (2019). Precariously placed: Home, housing and wellbeing for older renters. Health \& Place, 58, 102152. https://doi.org/10.1016/j.healthplace.2019.102152

Bell, C. (2017). "We feel like the king and queen": Western retirees in Bali, Indonesia. Asian Journal of Social Science, 45, 271-293. https://doi.org/10.1163/15685314-04503003

Botterill, K. (2017). Discordant lifestyle mobilities in East Asia: Privilege and precarity of British retirement in Thailand. Population, Space and Place, 23(5), 1-11. https://doi.org/10.1002/psp.2011

Brown, K. G. \& Cave, J. (2010). Island tourism: Marketing culture and heritage - editorial introduction to the special issue. International Journal of Culture, Tourism and Hospitality Research, 4(2), 87-95. https://doi.org/10.1108/17506181011045163

Brown, R. M. (2017). "The tourists still come, but they don't buy as much as before": Vulnerability and resilience in two Bay Island communities in the wake of the Global Financial Crisis. The Qualitative Report, 22(4), 1112-1136.

Burholt, V., Scharf, T., \& Walsh, K. (2013). Imagery and imaginary of islander identity: Older people and migration in Irish small-island communities. Journal of Rural Studies, 31, 112. https://doi.org/10.1016/j.jrurstud.2013.01.007

Clarke, A. (2006). Qualitative interviewing: Encountering ethical issues and challenges. Nurse Researcher, 13(4), 19-29. https://doi.org/10.7748/nr2006.07.13.4.19.c5987

Clarke, L. H., \& Bennett, E. (2013). You learn to live with all the things that are wrong with you': Gender and the experience of multiple chronic conditions in later life. Ageing and Society, 33: 342-360. https://doi.org/10.1017/s0144686x11001243

Coleman, T. M. (2012). Ageing-in-place on Waiheke Island, New Zealand: Experiencing 'place', 'being aged' and implications for wellbeing. Unpublished $\mathrm{PhD}$ Thesis, Geography, University of Auckland.

Coleman, T., \& Kearns, R. (2015). The role of bluespaces in experiencing place, aging and wellbeing: Insights from Waiheke Island, New Zealand. Health and Place, 35, 206-217. https://doi.org/10.1016/j.healthplace.2014.09.016

Coleman, T., Kearns, R. A., \& Wiles, J. (2016). Older adults' experiences of home maintenance issues and opportunities to maintain ageing in place. Housing Studies, 31(8), 964-983. https://doi.org/10.1080/02673037.2016.1164834

Colic-Peisker, V., Ong, R., \& Wood, G. (2015). Asset poverty, precarious housing and ontological security in older age: An Australian case study. International Journal of Housing Policy, 15(2), 167-186. https://doi.org/10.1080/14616718.2014.984827 
Costa-Font, J., Elvira, D., \& Mascarilla-Miró, O. (2009). 'Ageing in place'? Exploring elderly people's housing preferences in Spain. Urban Studies, 46(2), 295-316. https://doi.org/10.1177/0042098008099356

Craciun, C., \& Flick, U. (2014). "I will never be the granny with rosy cheeks": Perceptions of aging in precarious and financially secure middle-aged Germans. Journal of Aging Studies, 29, 78-87. https://doi.org/10.1016/j.jaging.2014.01.003

DeVerteuil, G., \& Golubchikov, O. (2016). Can resilience be redeemed? City, 20(1), $143-$ 151. https://doi.org/10.1080/13604813.2015.1125714

Garg, A. (2006). My experience of interviewing a "crusader participant": Tips for fellow researchers. International Journal of Qualitative Methods, 5(4), 70-74. https://doi.org/10.1177/160940690600500406

Golant, S. M. (2015). Residential normalcy and the enriched coping repertoires of successfully aging older adults. The Gerontologist, 55(1), 70-82. https://doi.org/10.1093/geront/gnu036

Gould, M. I., \& Moon, G. (2000). Problems of providing health care in British island communities. Social Science and Medicine, 50(2), 1081-1090. https://doi.org/10.1016/s0277-9536(99)00356-1

Green, R. (2005). Community perceptions of environmental and social change and tourism development on the island of Koh Samui, Thailand. Journal of Environmental Psychology, 25, 37-56. https://doi.org/10.1016/j.jenvp.2004.09.007

Grenier, A., Lloyd, L., \& Phillipson, C. (2017). Precarity in late life: Rethinking dementia as a 'frailed' old age. Sociology of Health and Illness, 39(2), 318-330. https://doi.org/10.1111/1467-9566.12476

Groot, S., Van Omen, C., Masters-Awatere, B., \& Tassell-Matamua, N. (2017). Precarity: Uncertain, unequal and insecure lives in Aotearoa New Zealand. Massey University Press: Auckland.

Grydehøj, A. (2019). Critical approaches to island geography. Area. Epub ahead of print. https://doi.org/10.1111/area.12546

Grydehøj, A. (2017). A future of island studies. Island Studies Journal, 12(1), 3-16. https://doi.org/10.24043/isj.1

Gulf News (2017a, October 5). A ferry back in time... Retrieved from http://www.waihekegulfnews.co.nz

Gulf News (2017b, January 12). Double decker bus backs into taxi. Retrieved from http://www.waihekegulfnews.co.nz

Gulf News (2017c, March 15). Enough already. Retrieved from http://www.waihekegulfnews.co.nz

Gulf News (2017d, July 20). High rents force staff off island. Retrieved from http://www.waihekegulfnews.co.nz

Gulf News (2017e, February 23). Loans to help clean up stream. Retrieved from http://www.waihekegulfnews.co.nz

Gulf News (2017f, August 3). Market takes stock - but keeps flavour. Retrieved from http://www.waihekegulfnews.co.nz

Gulf News (2017g, June 29). Our caring community. Retrieved from http://www.waihekegulfnews.co.nz 
Gulf News (2017h, August 31). Red Cross active in many quarters. Retrieved from http://www.waihekegulfnews.co.nz

Gulf News (2017i, June 22). Rural boundary is back. Retrieved from http://www.waihekegulfnews.co.nz

Gulf News (2017j, January 19). Sire, the peasants are revolting. Retrieved from http://www.waihekegulfnews.co.nz

Gulf News (2017k, February 15). The revolution is coming. Retrieved from http://www.waihekegulfnews.co.nz

Gulf News (20171, September 7). Through the looking glass. Retrieved from http://www.waihekegulfnews.co.nz

Gulf News (2017m, March 1). Too little, too late. Retrieved from http://www.waihekegulfnews.co.nz

Gulf News, (2016a, June 23). Getting a grip on our real housing needs. Retrieved from http://www.waihekegulfnews.co.nz

Gulf News (2016b, November 14). High cost of homelessness on Waiheke. Retrieved from http://www.waihekegulfnews.co.nz

Gulf News (2016c). Social services see huge housing problem. Retrieved from http://www.waihekegulfnews.co.nz

Gulf News (2016d, September 15). Time to speak up over our Waiheke bid. Retrieved from http://www.waihekegulfnews.co.nz

Harris, E., \& Nowicki, M. (2018). Cultural geographies of precarity. Cultural Geographies, 25(3), 387-391. https://doi.org/10.1177/1474474018762812

Hay, P. (2006). A phenomenology of islands. Island Studies Journal, 1(1), 19-42.

Hillcoat-Nallétamby, S., \& Ogg, J. (2014). Moving beyond 'ageing in place': Older people's dislikes about their home and neighbourhood environments as a motive for wishing to move. Ageing and Society, 34, 1771-1796. https://doi.org/10.1017/S0144686X13000482

Hong, G. (2017). Locating Zhuhai between land and sea: a relational production of Zhuhai, China, as an island city. Island Studies Journal, 12(2), 7-24. https://doi.org/10.24043/isj.16

Kearns, R. A. (2016). Placing observation in the research toolkit. In I. Hay (Ed.), Qualitative research methods in human geography (pp.313-333). Ontario: Oxford University Press.

Kearns, R., \& Collins, D. (2016). Aotearoa's archipelago: Reimagining New Zealand's island geographies. New Zealand Geographer, 72, 165-168. https://doi.org/10.1111/nzg.12140

Lawrence, J., Kearns, R. A., Park, J., Bryder, L., \& Worth, H. (2008). Discourses of disease: Representation of tuberculosis within New Zealand newspapers 2002-2004. Social Science and Medicine, 66, 727-739. https://doi.org/10.1016/j.socscimed.2007.10.015

Leung, A., Tanko, M., \& Burke, M. (2017). Bridges, tunnels, and ferries: Connectivity, transport, and the future of Hong Kong's outlying islands. Island Studies Journal, 12(2), 61-82. https://doi.org/10.24043/isj.24

Liamputtong, P. (2007). Researching the vulnerable: A guide to sensitive research methods. London: Sage. 
Little, P. (2016, December 17). Is Waiheke the new Hamptons? The New Zealand Herald. Retrieved from https://nzherald.co.nz

Maxwell, J., \& Chmiel, M. (2014). Notes toward a theory of qualitative data analysis. In U. Flick (Ed.), The SAGE handbook of qualitative data analysis (pp.21-34). Thousand Oaks: Sage.

McGarrol, S. (2017). The emotional challenges of conducting in-depth research into significant health issues in health geography: Reflections on emotional labour, fieldwork and life course. Area, 49(4), 436-442. https://doi.org/10.1111/area.12347

McKee, M., Reeves, A., Clair, A., \& Stuckler, D. (2017). Living on the edge: Precariousness and why it matters for health. Archives of Public Health, 75(13), 1-10. https://doi.org/10.1186/s13690-017-0183-y

Merriam, S., \& Tisdell, E. (2016). Qualitative research (4 ${ }^{\text {th }}$ Ed.). New York: Wiley \& Sons.

Mountz, A. (2011). The enforcement archipelago: Detention, haunting and asylum on islands. Political Geography, 30, 118-128. https://doi.org/10.1016/j.polgeo.2011.01.005

Nowicki, M. (2017). Bringing home the housing crisis: Domicide and precarity in Inner London. Unpublished $\mathrm{PhD}$ thesis, Royal Holloway University of London.

Pendall, R., Theodos, B., \& Franks, K. (2012). Vulnerable people, precarious housing, and regional resilience: An exploratory analysis. Housing Policy Debate, 22(2), 217-296. https://doi.org/10.1080/10511482.2011.648208

Pritchard, C. (2013, November 14). Paradise Island on Auckland's doorstep. AAP. Retrieved from www.stuff.co.nz

Róin, A. (2015). The multifaceted nature of home: Exploring the meaning of home among elderly people living in the Faroe Islands. Journal of Rural Studies, 39, 22-31. https://doi.org/10.1016/j.jrurstud.2015.03.002

Róin, A. (2014). Embodied ageing and categorisation work amongst retirees in the Faroe Islands. Journal of Aging Studies, 31, 83-92. https://doi.org/10.1016/j.jaging.2014.09.001

Royle, S. \& Scott, D. (1996). Accessibility and the Irish islands. Geography, 81(2), 111-119.

Stake, R. (1995). Data gathering. In The Art of Case Study Research (pp.49-68). Thousand Oaks: Sage.

Waiheke Community Board (2016). Essentially Waiheke: Refresh 2016. Report published online. Retrieved from http://shapeauckland.co.nz/media/1661/essentiallywaiheke draft-to-consultation 090816-final.pdf

Waite, L. (2009). A place and space for a critical geography of precarity? Geography Compass, 3(1), 412-433. https://doi.org/10.1111/j.1749-8198.2008.00184.x

Wiles, J. L., Wild, K., Kerse, N., \& Allen, R. E. S. (2012). Resilience from the point of view of older people: 'There's still life beyond a funny knee'. Social Science and Medicine, 74, 416-424. https://doi.org/10.1016/j.socscimed.2011.11.005

Wiles, J. L., Rolleston, A., Pillai, A., Broad, J., Teh, R., Gott, M. \& Kerse, N. (2017). Attachment to place in advanced age: A study of the LiLACS NZ cohort. Social Science and Medicine, 185, 27-27. https://doi.org/10.1016/j.socscimed.2017.05.006

Worth, N. (2016). Feeling precarious: Millennial women and work. Environment and Planning D: Society and Space, 34(4), 601-616. https://doi.org/10.1177/0263775815622211 
Laura Bates et al. 